\title{
Antioxidant Activity of Protein Hydrolysates Derived from Javanese Freshwater Fishes
}

\author{
Yuli Witono \\ Department of Agricultural Product \\ Technology \\ Faculty of Agricultural Technology, \\ University of Jember \\ Jember, Indonesia \\ yuliwitono.ftp@unej.ac.id
}

Riska Rian Fauziah

Department of Agricultural Product Technology

Faculty of Agricultural Technology,

University of Jember

Jember, Indonesia

\author{
Iwan Taruna \\ Department of Agricultural Engineering \\ Faculty of Agricultural Technology, \\ University of Jember \\ Jember, Indonesia
}

\author{
Maryanto \\ Department of Agricultural Product \\ Technology \\ Faculty of Agricultural Technology, \\ University of Jember \\ Jember, Indonesia
}

\author{
Wulan Suci Wahyuningtyas \\ Department of Agricultural Product Technology \\ Faculty of Agricultural Technology, \\ University of Jember \\ Jember, Indonesia
}

\begin{abstract}
Fish protein hydrolysates have been identified as the rich source of bioactive peptides. Thus, this study aims to determine the antioxidant activity of protein hydrolysates derived from common barb (Rasbora jacobsoni) and java carp (Barbonymus gonionotus). Therefore, in this study, two types of freshwater fishes were evaluated as a raw material to obtain protein hydrolysates exhibiting antioxidant activity. The fish's protein was hydrolyzed by biduri protease with a concentration of 1,2 and $3 \%(v / w)$ for 3 hours. Afterwards, the resulted dry hydrolysates were observed to determine the degree of hydrolysis, antioxidant activity (DPPH and reducing power), amino acid composition, and molecular weight. The result shows that the protein hydrolysates derived from common barb and java carp fish had percent value of inhibition (\%RSA) respectively of $42.70 \%$ and $53.21 \%$, an IC $_{50}$ value of $1159.76 \mathrm{ppm}$ and $935.84 \mathrm{ppm}$, reducing power value of 0.508 and 0.524 . The protein hydrolysates derived from java carp fish had 15 kinds of an amino acid such as glutamic acid, aspartic acid and lysine, respectively of $13.34 \%$; $8.36 \%$; and $8.20 \%$. The molecular weight distribution of protein hydrolysates derived from java carp fish had a value of about $23.09 \mathrm{kDa} ; 59.08 \mathrm{kDa}$.
\end{abstract}

Keywords-Amino Acid, Antioxidant Activity, Javanese Freshwater Fishes, Protein Hydrolysates.

\section{INTRODUCTION}

As a primary potential resource for Indonesian fishery, fishery products can be derived from Javanese fishery, especially from East Java. Several types of fish are widely known to have great potential including common barb and java carp normally derived from fresh water. However, despite having good source of protein, they still have a low economic value. Thus, it will be of topical issue to develop their upgrading processes to add the product value of this underutilized raw material by way of processing them into protein hydrolysates. The protein hydrolysates are the derivative products of the enzymatic conversion of native proteins into smaller peptides with 2-20 amino acids [1]. Hydrolysis process can be carried out chemically or enzymatically. Enzymatic hydrolysis is the safest method and is more profitable than chemical one because enzymatic hydrolysis generates free amino acids and varies short-chain peptides. There are several proteases that can be used for hydrolysis process including that derived from biduri. Protease derived from biduri (Calotropis gigantea) plant is also a local plant source from tropical countries including Indonesia. The previous studies have shown that the extract of the biduri either from the stems, sap or leaves have a great potential as a source of protease [2]. The hydrolysates product has a wider range of uses in the food industry. No wonder that protein hydrolysates come up with interesting potentials for food applications like flavor enhancers in confectionary products, protein supplement, and beverage stabilizer [3].

Fish protein hydrolysates have been identified as the rich source of bioactive peptides with valuable pharmaceutical potentials [4]. Countless researches of fish protein hydrolysates have revealed numerous bioactivities such as antioxidant, antihypertensive, antithrombotic, immunomodulatory, and antimicrobial among others [5]. The presence of hydrophobic amino acid such as Pro, Ala, Val and Leu as the N-terminus and aromatic amino acid Tyr, Val, Met, Ile, Leu, Glu and Trp as the C-terminus is suggested to contribute to the antioxidant capacity of the corresponding peptides [6]. The presence of hydrophobic and aromatic amino acids such as Trp, Pro, Gly, Val, and Leu leads is known to enhance radical scavenging ability that was identified from Bluefin leatherjacket heads [7]. On this basis, this study aims to determine the antioxidant activity of common barb and java carp fish. Javanese freshwater fish, namely common barb and java carp were evaluated as a raw material to obtain fish protein hydrolysates exhibiting antioxidant activity.

\section{METHODS}

\section{A. Materials}

Common barb and Java carp fish were purchased from Tanjung Market of Jember district, Indonesia, while 'Biduri' (Calotropis gigantea) was collected from the coast of Papuma beach, Jember, Indonesia as a source of 
exopeptidase. The chemical analytical grade was purchased from Sigma (Sigma - Aldrich).

\section{B. Production of Fish Protein Hydrolysates}

In the first place, Common barb and Java carp fish were filleted, deboned and eviscerated to remove their viscera and gonads. Then, the fish meat was cleaned manually under tap water to remove residual after the process of deboning and evisceration. Fish protein hydrolysates as described by Bhaskar et al. [8] are produced with slight modification. For enzymatic hydrolysis, common barb and java carp were homogenized with distilled water (1:2 $(\mathrm{w} / \mathrm{v}))$. The mixture was adjusted to the enzyme $\mathrm{pH}$ of 7 and temperature of $55^{\circ} \mathrm{C}$. The sample was added by biduri protease with different concentration $(1 \%, 2 \%$ and $3 \%$ respectively $(\mathrm{v} / \mathrm{w}))$ and was incubated for 3 hours. Afterwards, all solution was heated at $85^{\circ} \mathrm{C}$ for $20 \mathrm{~min}$ to inactivate biduri protease. The solution was incubated at $10^{\circ} \mathrm{C}$ for 24 hours and then centrifuged at $3500 \mathrm{rpm}$ for 30 $\min$ at $4^{\circ} \mathrm{C}$. The supernatant was collected and dried using freeze drying. Furthermore, antioxidant activity was observed by way of DPPH (diphenyl picryl hydrazyl) radical scavenging and reducing power. Other parameters observed include the degree of hydrolysis, amino acid profile, and molecular weight.

\section{Degree of Hydrolysis}

Degree of hydrolysis (DH) is defined as the percentage of peptide bonds cleaved compared to the total number of peptide bonds in the substrate [9]. Degree of hydrolysis was estimated according to Haslaniza [10]. $20 \mathrm{ml}$ of protein hydrolyzate is cultivated by $20 \mathrm{ml}$ TCA $20 \%(\mathrm{w} / \mathrm{v})$. Then the mixture was allowed to stand for 30 minutes to allow precipitation before being centrifuged at $7800 \mathrm{rpm}$ for 15 minutes. The supernatant analyzed its nitrogen content using Kjeldahl method [11].

\section{DPPH Radical Scavenging Activities}

DPPH radical scavenging methods as reported by Shimada et al. [12] which requires a low amount of sample was employed in that $1.5 \mathrm{ml}$ of each sample $(0.001 \mathrm{~g} / \mathrm{ml})$ was mixed with $1.5 \mathrm{ml}$ of DPPH at $0.1 \mathrm{mM}$ in ethanol. The mixture was kept at room temperature in the dark for 30 min. The reduction of DPPH radical was measured at 517 nm. A blank was run in the same way by using distilled water instead of sample, and sample control was also made for each sample by adding ethanol instead of DPPH solution.

\section{E. Reducing Power}

The reducing power of fish protein hydrolysates was determined by the method of Oyaizu [13] with slight modification. $1 \mathrm{ml}$ of each hydrolysate $(0.001 \mathrm{~g} / \mathrm{ml})$ was added to $2.5 \mathrm{ml}$ of $0.2 \mathrm{M}$ phosphate buffer ( $\mathrm{pH} \mathrm{6.6)}$ and 2.5 $\mathrm{mL}$ of $1 \%$ potassium ferricyanide. The reaction mixture was incubated at $50^{\circ} \mathrm{C}$ for $20 \mathrm{~min}$ and then $2.5 \mathrm{ml}$ of $10 \%$ TCA were added. A $2.5 \mathrm{~mL}$ aliquot of the supernatant was mixed with $2.5 \mathrm{ml}$ of distilled water and $0.5 \mathrm{ml}$ of ferric chloride. The absorbance of the resulting solution was recorded at $700 \mathrm{~nm}$ after $10 \mathrm{~min}$. An equivalent volume of distilled water instead of the sample was used as a control.

\section{F. Amino Acid Profile}

Amino acid profile was analyzed based on AOAC [11]. Powdered sample (3 mg) was hydrolyzed with $\mathrm{HCl} 6 \mathrm{M}$ at $110^{\circ} \mathrm{C}$ for 24 hours. After hydrolysis, the acid was removed by rotary evaporation. The sample was resuspended on kalium borate buffer $\mathrm{pH} 10.4$. Then, $10 \mu \mathrm{L}$ of the sample solution was mixed with $25 \mu \mathrm{L}$ o-phthalaldehyde (OPA). The mixed solution (both sample and standard) was allowed to stand for 1 minute to complete the derivation. Afterwards, About $5 \mu \mathrm{L}$ of standard solution was injected into HPLC column and waited until the separation of all amino acids completed. A gradient mobile phase of sodium acetate 0.1 $\mathrm{M}$ pH 7.2 and methanol (9:1) elute sample for amino acid was separated trough $\mathrm{C} 18$ column reversed-phase octadecyl dymethilsilane particles. Fluorescence detection was realized using an excitation-emission wavelength of 360 and $455 \mathrm{~nm}$ respectively

\section{G. Molecular Weight Distribution}

The molecular weight distribution of the protein hydrolysates was analyzed using SDS PAGE (sodium dodecyl sulfate-polyacrylamide gel electrophoresis) by following the method developed by Laemmli [14] with some modification. About $0.25 \mathrm{~g}$ of sample was homogenized with $0.75 \mathrm{ml}$ buffer extraction. Then, the homogenate was centrifuged at $12.000 \mathrm{rpm}$ for $10 \mathrm{~min}$ at $4^{\circ} \mathrm{C}$. The protein content of the supernatant was analyzed using the method of Laemmli [14]. Then, the supernatant was added by loading buffer and it was denatured by heating it at $100^{\circ} \mathrm{C}$ for $3 \mathrm{~min}$. After that, the sample was incorporated in the gel and separated using SDS PAGE with acrylamide (concentration 15\%) which had an electric current of 50-95 V for 5 hours.

\section{H. Data Analysis}

The research data were processed using Microsoft Excel Software and were analyzed descriptively. Then, to facilitate its interpretation, the average parameters values are presented in the table and histograms.

\section{RESUlTS \& DISCUSSION}

\section{A. Degree of Hydrolysis}

Degree of Hydrolysis (DH), which is defined as the percentage of peptide bonds cleaved, is one of the basic parameters to describe the properties of protein hydrolysates [15]. As an illustration, the degree of hydrolysis of common barb and java carp protein hydrolysates with different concentration of biduri protease is shown in Fig 1.

The lowest value of $39.38 \pm 0.64$ was detected in common barb fish protein hydrolysates with $1 \%(\mathrm{v} / \mathrm{w})$ addition of biduri protease. Meanwhile, the highest value of $77.99 \pm 0.87$ was detected in java carp protein hydrolysates with $3 \%$ $(\mathrm{v} / \mathrm{w})$ addition of biduri protease. Previous research carried out by Haslaniza [10] shows that different enzyme concentration and hydrolysis time, lead to differences in the degree of hydrolysis value. The increasing $\mathrm{DH}$ value is primarily caused by the increase of peptides and amino acids dissolved in TCA resulted from the breaking of peptide bonds during the hydrolysis process [10]. 


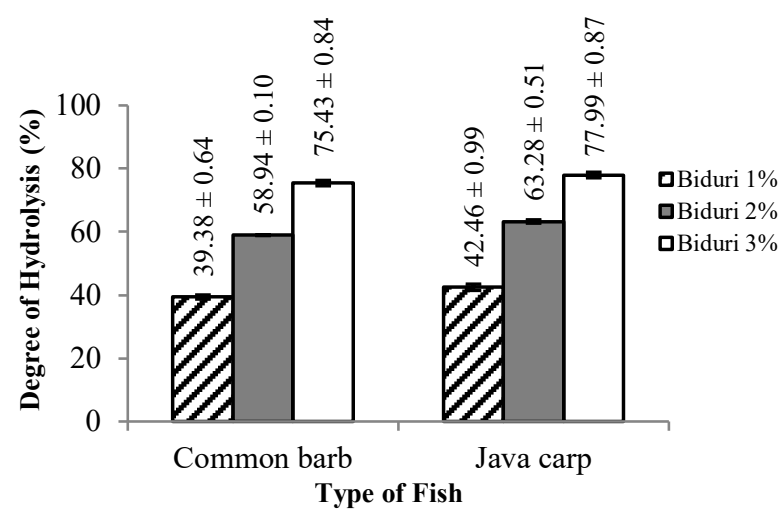

Figure 1. Degree of hydrolysis of common barb and java carp protein hydrolysates with different concentration of biduri protease.

\section{B. DPPH Radical Scavenging Activities}

According to Molyneux [16], a compound is said to have antioxidant activity when it is able to donate its hydrogen atom. To illustrate this, radical scavenging activity of common barb and java carp protein hydrolysates with different concentration of biduri protease is shown in Fig 2.

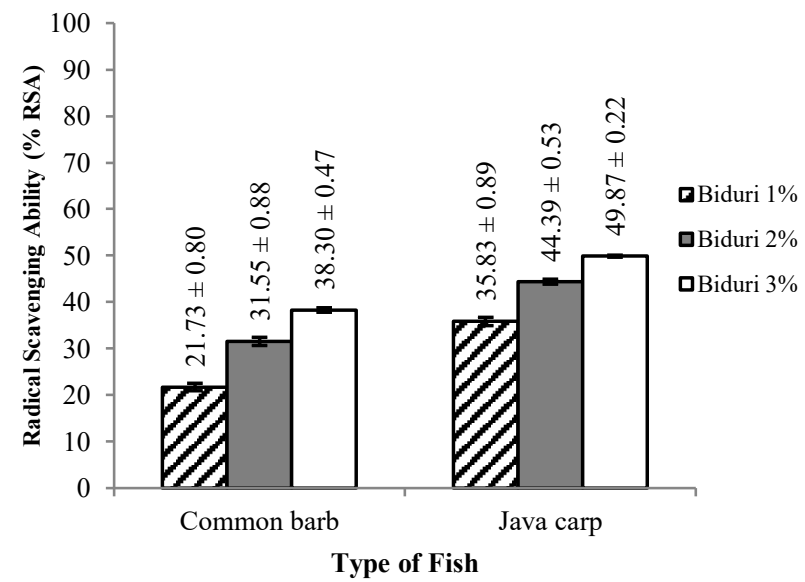

Figure 2. Radical scavenging ability of common barb and java carp fish protein hydrolysates with different concentration of biduri protease.

The lowest radical scavenging ability value of $21.73 \pm 0.80$ was detected in common barb fish protein hydrolysates with the addition of $1 \%(\mathrm{v} / \mathrm{w})$ biduri protease. While the highest radical scavenging value of $49.87 \pm 0.22$ was detected in java carp protein hydrolysates with the addition of $3 \%(\mathrm{v} / \mathrm{w})$ biduri protease. The higher concentration of biduri protease was added, leading to the higher percentage value of inhibition. In general, $3 \%(\mathrm{v} / \mathrm{w})$ addition of biduri protease has the highest percentage of inhibition. When enzyme concentration has increased, the amount of peptides and free amino acid produced in the hydrolysates product also increases. Fish protein hydrolysates which have the high radical scavenging and degree of hydrolysis value were dried with a freeze-drying process and its antioxidant activity was analyzed using $\mathrm{IC}_{50}$ value. $\mathrm{IC}_{50}$ value of common barb and java carp fish protein hydrolysates were shown in Fig 3.

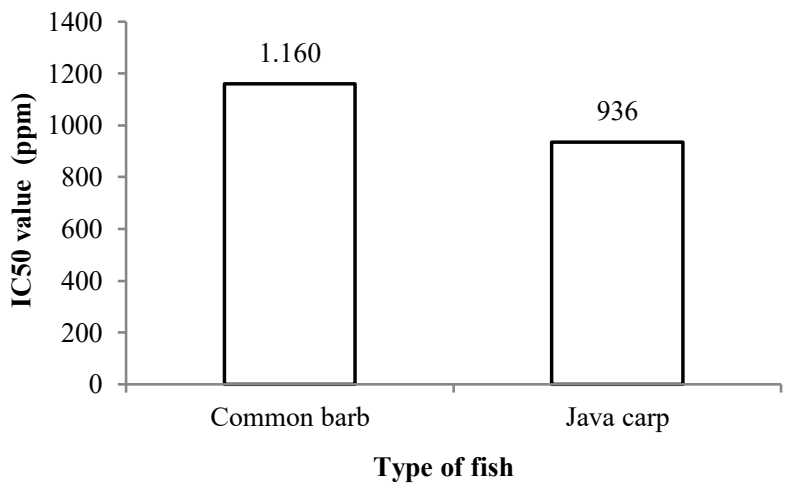

Figure 3. $\mathrm{IC}_{50}$ value of common barb and java carp fish protein hydrolysates

The sample that has low antioxidant activity is common barb protein hydrolysates with $\mathrm{IC}_{50}$ value of about 1.160 $\mathrm{ppm}$. While the sample with high antioxidant activity is java carp protein hydrolysates with $\mathrm{IC}_{50}$ value of about 935.84 $\mathrm{ppm}$. A compound is said to be a very powerful antioxidant if the IC50 value is less than $0.05 \mathrm{mg} / \mathrm{mL}(<50 \mathrm{ppm})$, strong if $\mathrm{IC}_{50}$ values is about $0.05-0.10 \mathrm{mg} / \mathrm{mL}(50-100 \mathrm{ppm})$, medium if $\mathrm{IC}_{50}$ value is about $0.10-0.15 \mathrm{mg} / \mathrm{mL}(100-150$ $\mathrm{ppm})$, and weak if $\mathrm{IC}_{50}$ value is about $0.15-0.20 \mathrm{mg} / \mathrm{mL}$

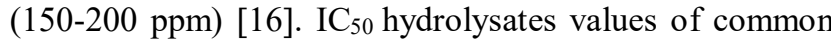
barb and java carp fish protein hydrolysates are ranged from 935.84 to $1.160 \mathrm{ppm}$. This is an indication that fish protein hydrolysates have been identified as the rich source of bioactive peptides with valuable pharmaceutical potentials as an antioxidant [4]. The protein hydrolysates of common barb and java carp have very weak antioxidant activity, because the value are more than $0.20 \mathrm{mg} / \mathrm{mL}$ or $200 \mathrm{ppm}$. As a comparison, the antioxidant of BHT (Butylated hydroxytoluene) which is a synthetic antioxidant, has an $\mathrm{IC}_{50}$ value of only about $9.30 \mathrm{ppm}$, because protein hydrolysates sample are constituted of many compounds which are not merely antioxidant, while BHT consists of pure antioxidant.

\section{Reducing Power}

Reducing power analysis was conducted to determine the ability of a substance to produce a secondary antioxidant. Reducing power value of common barb and java carp protein hydrolysates is presented in Fig 4.

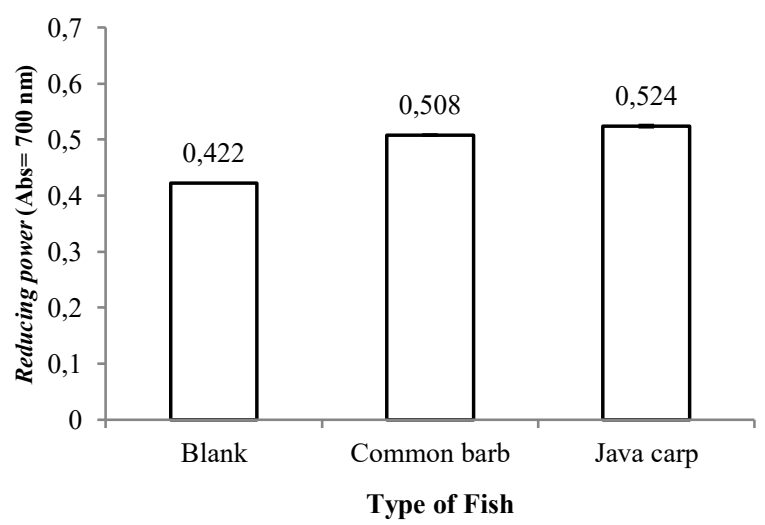

Figure 4. Reducing power value of common barb and java carp fish protein hydrolysates 
It is obvious that the sample having high reducing power value is Java carp protein hydrolysates of about $0.524 \pm 0,002$, while the sample with low reducing power value is common barb fish protein hydrolysates with the value at about $0,508 \pm 0,002$. As a comparison, the researcher also measured the absorbance of blanks to determine the increase of absorbance value. The absorbance value shows an increase at about 0.079-0.102 from blank absorbance. The yellow color of the test solution changes to various shades of green and blue depending on the reducing power of each compound. This indicates that the protein hydrolysates of common barb and java carp contain secondary antioxidants that can reduce radicals by electron transfer, whereas the $\mathrm{Fe}^{3+} /\left[\mathrm{Fe}(\mathrm{CN})_{6}\right]^{3-} /$ contains ferricyanide complex to the ferrous form like $\mathrm{Fe}^{2+} /$ $\left[\mathrm{Fe}(\mathrm{CN})_{6}\right]^{4-} /$ ferrocyanide [17]. The changes of yellow color of the test solution to various shades of green and blue depend on the reducing power of each compound.

\section{Amino Acid Profile}

Amino acid profile of java carp protein hydrolysates was analyzed to determine the type and amount of amino acids contained in protein hydrolysates [18]. Amino acid profile of java carp protein hydrolysates is shown in Table 1 .

Table 1. Amino acid profile of java carp protein hydrolysates

\begin{tabular}{lc}
\hline Amino Acid & Composition $\%(\mathrm{w} / \mathrm{w})$ \\
\hline Aspartate & 8.80 \\
Glutamate & 13.96 \\
Serine & 3.48 \\
Histidine & 2.24 \\
Glycine & 5.30 \\
Threonine & 3.90 \\
Arginine & 5.74 \\
Alanine & 5.82 \\
Tyrosine & 2.79 \\
Methionine & 2.93 \\
Valine & 4.06 \\
Phenylalanine & 3.75 \\
Isoleucine & 3.74 \\
Leucine & 7.01 \\
Lysine & 8.87 \\
\hline
\end{tabular}

According to Klompong [19], some types of amino acids have excellent potential as the source of antioxidants. Protein hydrolysates which contain hydrophobic amino acids, such as leucine, alanine, tryptophan, and phenylalanine, have high antioxidant activity [20]. Hydrophobic amino acids such as tryptophan may work as a hydrogen donor because of the capabilities of the phenolic and indolic groups. Java carp protein hydrolysates are known to contain some of these amino acids even with relatively small amounts. They contain leucine, alanine, tryptophan and phenylalanine respectively at about $7.01 \%$; $5.82 \% ; 3.9 \%$; and $3.75 \% \mathrm{~s}$.

\section{E. Molecular Weight Distribution}

Molecular weight analysis was performed to determine the molecular weight of proteins from protein hydrolysates after hydrolysis process using protease enzymes. The molecular weight distribution of java carp fish protein hydrolysates is shown in Fig 5.

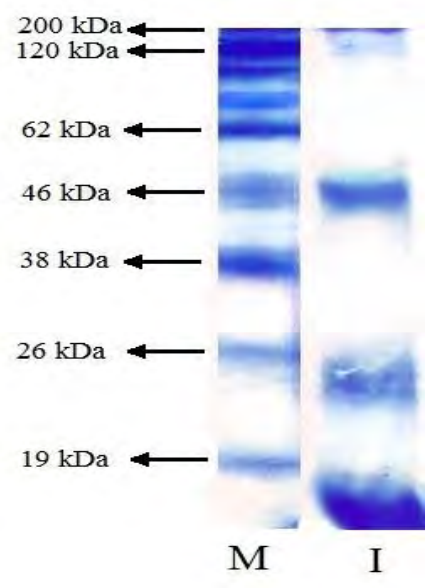

Figure 5. The molecular weight distribution of java carp fish protein hydrolysates

In java carp protein hydrolysates, there are two bands with value of 23.09-59.08 kDa. Hydrolysis of peptide bonds will cause some changes in protein properties that increase solubility, and reduced molecular weight of proteins or polypeptides [21]. According to Belkaaloul [22], during the process of protein hydrolysis by proteolytic enzymes, the proteins are broken down into smaller protein fractions. Many types of peptides which are known to have positive effects in the body usually have a low molecular weight of below $100 \mathrm{kDa}$ and consist of 3 to 10 amino acids [23]. Small molecular weights can be easily absorbed by the body and are easier to bind free radicals than large molecular weight peptides [21]. In addition, Suárez [24] reported that sarcoplasmic proteins showed molecular weight of 97,60 , $51,41,36,34,27$, and $25 \mathrm{kDa}$. In addition, collagen extracted from frame, skin and the refiner discharge showed a molecular weight of about $100 \mathrm{kDa}(\alpha 1$ and $\alpha 2$ chains) and $200 \mathrm{kDa}$ ( $\beta$-component) [25].

\section{CONCLUSION}

It is revealed that protein hydrolysates derived from common barb and java carp fish has percent value of inhibition (\%RSA) respectively at $42.70 \% \pm 0.20$ and $53.21 \% \pm 0.66, \mathrm{IC}_{50}$ value about $1159.76 \mathrm{ppm}$ and 935.84 ppm, reducing power value of about 0.508 and 0.524 . Protein hydrolysates derived from java carp fish have 15 kinds of amino acid such as glutamic acid, aspartic acid and lysine, respectively at about $13.34 \% ; 8.36 \%$; and $8.20 \%$. The molecular weight distribution of protein hydrolysates derived from java carp fish have a value at about $23.09 \mathrm{kDa}$; $59.08 \mathrm{kDa}$. Therefore, it is conclusive that protein hydrolysates derived from java carp and common barb have a potential source of bioactive and functional food ingredients.

\section{ACKNOWLEDGMENTS}

The author would like to exert gratitude to the Directorate of Research and Development of the Indonesia Ministry of Research, Technology and Higher Education for supporting the provision of a competency-based research grant in 2018 . 


\section{REFERENCES}

[1] Hamid, S.A., Halim, N.R.A., Sarbon, N.M.. Optimization of enzymatic hydrolysis conditions of Golden Apple snail (Pomacea canaliculata) protein by Alcalase. Int. Food Res. J. 22 (4), 1615-1622, 2015 .

[2] Witono, Y. Biduri Enzymes: Potential Active Agent for Food Processing. Pustaka Radja. Surabaya, 2013.

[3] Balti, R., Bougatef, A., El-Hadj Ali, N., Zekri, D., Barkia, A., Nasri, M. Influence of degree of hydrolysis on functional properties of angiotensin I-converting enzyme inhibitory activity of protein hydrolysates from cuttlefish (Sepia officinalis) by-products. J. Sci. Food Agr. 90, 2006-2014, 2010.

[4] Ren J, Zhao M, Shi J, Wang J, Jiang Y, Cui C, Kukuda Y, Xue JS. Optimization of antioxidant Peptide production from grass carp sarcoplasmic protein using response surface methodology. Food and science technology. Vol. (41): 1624-1632, 2008.

[5] Je, J.Y., Lee, K.H., Lee, M.H., Ahn, C.B. Antioxidant and Antihypertensive Protein Hydrolysates Produced from Tuna Liver by Enzymatic Hydrolysis. Food Research International. Vol (42): 12661272, 2008.

[6] Giri, A., \& Ohsima, T. Bioactive marine peptides: Nutraceutical Value and Novel Approaches. Advances in Food and Nutrition Research, 65, 73-105, 2012

[7] Chi, C.F., Wang, B., Wang, Y.M., Zhan, B., \& Deng, S.G. Isolation and characterization of three antioxidant peptides from protein hydrolysate of Bluefin leatherjacket (Navodon septentrionalis) heads. Journal of Agricultural and Food Chemistry, 55, 10918-10923, 2015.

[8] Bhaskar, N., Benila, T., Radha, C., Lalitha, R.G. Optimization of Enzymatic Hydrolysis of Visceral Waste Proteins of Catla (Catla catla) for Preparing Protein Hydrolysate Using a Commercial Protease. Journal of Bioresource Technology. Vol. 99 (10): 335-343, 2008

[9] Pedro J. Garcia-Moreno, Irineu Batista, Carla Pires, Narcisa M. Bandarra, F. Javier Espejo-Carpio, Antonio Guadix, Emilia M. Guadix. Antioxidant Activity of Protein Hydrolysates obtained from Discarded Mediterranean Fish Species. Food Research International. 05177: 8, 2014

[10] Haslaniza, H. The Effects of Enzyme Concentration, Temperature and Incubation Time on Nitrogen Content and Degree of Hydrolysis of Protein Precipitate from Cockle (Anadara granosa) meat wash water. International Food Research Journal. Vol. (17): 147-152, 2010

[11] AOAC. Official Methods of Analysis. Association of Official Analytical Chemists. Benjamin Franklin Station, Washington. 2005.

[12] Shimada, K, Fujikawa, K, Yahara, K, Nakamura, T. Antioxidative Properties of Xanthan on the Antioxidation of Soybean Oil in Cyclodextrin Emulsion. Journal Agricultural Food Chemistry. Vol. 40 (1): 945-948, 1992

[13] Oyaizu M. Studies on product of browning reaction prepared from glucose amine. Japan Journal Nutrition. Vol. (44): 307- 315, 1986.

[14] Laemmli U.K. Cleavage of Structural Protein during the Assembly of the Head of Bacteriophage T4. Nature. Vol. (227): 680-685, 1970.

[15] Šližytė, R., E. Daukšas, E. Falch, I. Storrø and T. Rustad. Characteristics of protein fractions generated from hydrolyzed cod (Gadus morhua) by-products. Process Biochem. Vol. 40: 20212033, 2005.

[16] Molyneux, P. The Use of The Stable Free Radical Diphenylpicrylhydrazyl (DPPH) for Estimating Antioxidant Activity, Songklanakarin. Journal of Science and Technology. Vol. 26 (2): 211-21, 2004

[17] Ferreira, I. C. F. R., Baptista, P., Vilas-Boas, M. \& Barros, L. Freeradical scavenging capacity and reducing power of wild edible mushrooms from northeast Portugal: Individual cap and stipe activity. Food Chemistry 100: 1511-1516, 2007.

[18] Muchtadi, T., Sugiyono, Fitriyono, A. Food Science. Alfabeta, Bandung. 2012

[19] Klompong, V., Benjakul, S., Yachai, M., Vissesanguan, W., Shahidi, F., Hayes, K.D. Amino Acid Composition and Antioxidative Peptides from Protein Hydrolysate of Yellow Stripe Trevally (Selaroides leptolepis). Journal Food Science. Vol. 74 (2): 126-133, 2009.
[20] Mendis, E., Rajapakse, N., Kim, S. K. Antioxidant Properties of a Radical Scavenging Peptide Purified from Enzymatically Prepared Fish Skin Gelatin Hydrolysate. Journal of Agricultural and Food Chemistry. Vol. (53): 581-587, 2005.

[21] Pan, B., Ricci, M.S., Trout, B. L. A Molecular Mechanism of Hydrolysis of Peptide Bonds at Neutral pH using a Model Compound. Journal of Physical Chemistry. Vol. 115 (19): 59595970, 2010.

[22] Belkaaloul A., Checroun A., Ait-Abdesalam A.I., Saidi, D., and Kherouoa, O. Growth, Acidification and Proteolysis Performance of Two co-cultures (Lactobacillus plantarum - Bifidobacterium longum and Streptococcus thermophilus bifidobacterium longum). African Journal of Biotechnology. Vol. 9 (10): 1463-1469, 2010

[23] Prastari, C., Yasni, S., Nurilmala, M. Characteristic of Snakehead Fish Protein that's Potential as Antihyperglycemic. Indonesia Fishery Product Processing Community. Vol. 20 (2): 413-423, 2017.

[24] Suárez, M. D., Martínez, T. F., Sáez, M. I., Morales, A. E., \& GarcíaGallego, M. Effects of dietary restriction on post-mortem changes in white muscle of sea bream (Sparus aurata). Aquaculture, 307, 4955,2010

[25] Kim, J. S., \& Park, J. W. Characterization of acid-soluble collagen from Pacific whiting surimi processing byproducts. Journal of Food Science, 69, 637-642, 2004. 